\title{
Effects of Ilex Paraguariensis Polyphenols on Magnesium Absortion and Iron Bioavailability: Preliminary Study
}

\author{
Lucila Sánchez Boado $^{1}$, Raquel María Fretes ${ }^{1} \&$ Luis Alberto Brumovsky ${ }^{1}$ \\ ${ }^{1}$ National University of Misiones, Faculty of Exact Sciences, Chemistry and Natural Sciences, Argentina \\ Correspondence: Lucila Sánchez Boado, National University of Misiones, Faculty of Exact Sciences, Chemistry \\ and Natural Sciences, Argentina. E-mail: 1sboado@fceqyn.unam.edu.ar
}

Received: October 18, 2017

Accepted: November 6, 2017 Online Published: March 12, 2018

doi:10.5539/jfr.v7n2p114

URL: https://doi.org/10.5539/jfr.v7n2p114

\begin{abstract}
Yerba maté (Ilex paraguariensis) is a native plant of South America widely consumed as hot infusion. It is a vegetable that has many bioactive compounds, such as caffeine, theobromine theophylline and saponins, phenolic compounds, mainly chlorogenic acids and dicaffeoylquinic acids, and minerals as $\mathrm{Fe}, \mathrm{Ca}, \mathrm{K} \mathrm{y} \mathrm{Mg}$, which have many beneficial properties for the health. Polyphenols have the property of chelating the transition metals, as iron and magnesium, decreasing their bioavailability. Iron deficiency anaemia and subclinical hypomagnesemia is observed in the American population. Women at childbearing age belong to a specially vulnerable group. The aim of this work was to evaluate the "in vivo" effect of the polyphenols from yerba maté infusions, consumed in their traditional form, on the bioavailability of $\mathrm{Fe}$ and $\mathrm{Mg}$ in the diet. Eleven healhty young female volunteers participated in the magnesium and iron study. After the first blood sample was taken (time 0), the volunteers ingested $300 \mathrm{~mL}$ of yerba maté infusions, ferrous sulfate or yerba maté infusions plus ferrous sulfate at $50{ }^{\circ} \mathrm{C}$ in no more than 5 minutes. They remained seated at a comfortable temperature throughout the study. Blood samples were taken 20,40,50,60,80, 100 and 120 minutes after ingestion.The yerba maté infusions prepared in their traditional form of "hot maté", which containining an average of $4.68 \pm$ $0.54 \mathrm{GAE} / \mathrm{L}$ of polyphenols, have an inhibitory effect on the bioavailability of the magnesium and mainly on non-heminic Fe consumed as ferrous sulphate of the $76 \pm 10 \%$.
\end{abstract}

Keywords: bioavailability, Ilex paraguariensis, in vivo, iron, magnesium, polyphenols

\section{Introduction}

Yerba mate (YM), Ilex paraguariensis is a native plant of the region of South America widely consumed as infusion. It's a vegetable that has many bioactive compounds, such as caffeine, theobromine and theophylline, phenolic compounds, mainly chlorogenic acids and dicaffeoylquinic acids, saponins and minerals as $\mathrm{Fe}, \mathrm{Ca}, \mathrm{K}$ y $\mathrm{Mg}$ mainly, which have many beneficial properties for the health. Consumption of YM infusions would signifcantly contribute to the overall antioxidant intake, providing high amounts of cafeoylquinic acid derivatives (Bravo, Goya \& Lecumberri, 2007) (Bastos et al., 2014) (Heck, Schmalko \& De Mejia, 2008). It was determined that YM infusions have cytotoxic activity and by inhibition of topoisomerase II may contribute to the general chemopreventive activity (Ramirez-Mares, Chandra \&Mejia, 2004) (Bracesco, Sanchez, Contreras, Menini \& Gugliucci, 2010). Some authors determined that YM infusion consumption is associated with higher bone mineral density in postmenopausal women (Conforti, Gallo \&Saraví, 2012). Other authors report that the presence of polyphenols in the YM infusion has a favorable effect on bone tissue and can mitigate the negative effect of caffeine (Brun et al., 2015). It has also been reported that there has been an inverse association between YM infusion consumption and Parkinson's disease (Gatto, Melcon, Parisi, Bartoloni \& Gonzalez, 2015). Antiherpes activity was also detected in the crude extract obtained from Ilex paraguariensis leave (Lückemeyer et al., 2012).

In Argentina, Paraguay, Brazil and Uruguay Yerba mate consumption is very high, either in the traditional form of hot mate, tea mate in tea bags or cold mate (tereré). Hot mate consists of putting between 30 and $50 \mathrm{~g}$ of yerba mate in a gourd, and a device similar to a straw (bombilla) with a filter on its end is inserted into the yerba mate. Then fractions of approximately $30 \mathrm{~mL}$ of hot water $\left(70^{\circ} \mathrm{C}\right.$ to $\left.85^{\circ} \mathrm{C}\right)$ are poured repeatedly on the yerba mate, to extract the infusion through the "bombilla". Yerba mate infusions contain a high amount of polyphenols, mainly caffeoylquinic acids. 
Due to the increasing consumption of refined foods and the decrease in vegetable and fruit intake, subclinical hypomagnesemia is observed in the American population. Part of the problem is that soils are becoming deficient in minerals. In the last 60 years the $\mathrm{Mg}$ in the content of fruits and vegetables decreased in $20 \%$ and $30 \%$ (Worthington 2001). In additionto this, the Western diet contains more refined grains and processed foods. Estimates are that $80 \%$ to $90 \%$ of magnesium is lost during food processing. Thus, it is estimated that $2.5 \%$ to $15 \%$ of the world population suffers some degree of hypomagnesemia (Belluci et al., 2013). Prevalence of hypomagnesemia varies widely as reported in previous studies, being $14.5 \%$ in an unselected German population, $11.8 \%$ in Indian subjects and sub-optimal $\mathrm{Mg}$ levels were found in $14.6 \%$ of the total Iranian urban population (Syedmoradi, Ghasemi, Zahediasl \& Azizi, 2011). The Recommended Dietary Allowances (RDA) of magnesium for women aged 29 to 30 years old is $310 \mathrm{mg}$ of $\mathrm{Mg}$ and women aged 31 to 50 years old is $320 \mathrm{mg}$ of $\mathrm{Mg}$ to according to the Institute of Medicine. Food and Nutrition Board (1997)

$\mathrm{Mg}$ is involved in more than 300 enzymatic reactions. The main part of body magnesium is located in the bones. Part of this magnesium - absorbed by the bone surface - is in equilibrium with the extracellular magnesium. At reduced plasma concentrations magnesium can be rapidly released from the bone surface and at increased plasma concentrations magnesium is bound to the surface (Vormann, 2003).

Magnesium that is ingested with food is exclusively absorbed as $\mathrm{Mg}^{+2}$ ions within the human small intestine, mainly in jejunum and ileum. Approximately one third of the magnesium consumed is absorbed in the process of renal resorption, since the rest is excreted with the faeces. Reabsorbed magnesium is mainly excreted through the urine and in small amounts through the gallbladder and sweat (Francisco \& Rodríguez, 2013) (de Baaij, Hoenderop \& Bindels, 2015).

Low serum $\mathrm{Mg}^{+2}$ values are associated with a wide range of neurological diseases such as migraine, depression, Parkinson's disease, brain damage, stroke and epilepsy. Magnesium is essential for maintaining the physiological functions of brain, heart and skeletal muscle (de Baaij, Hoenderop \& Bindels, 2015). Magnesium deficiency is observed in chronic malnutrition, diarrhea, diabetes, alcoholism, acidosis, renal disease and in patients who consume diuretics (Barbagallo \& Dominguez, 2007).

Among the most common nutritional deficiencies is iron deficiency anaemia according to the World Health Organization (2015). One of the causes of this anaemia is insufficient intake of iron in the diet to replace menstrual losses. Especially vulnerable groups are those of children and women at childbearing age. According to studies (Kogan, Abeyá Gilardón \& Biglieri, 2008) in northwest Argentina, 22.6\% of women between 18 and 49 years old suffer from iron deficiency anaemia, the highest value in the country.

The yerba mate infusions prepared in their traditional form of hot mate have $1.4 \pm 0.2 \mathrm{mg}$ of Fe / $\mathrm{L}$, this amount in the case of women at childbearing age can reach $7.1 \%$ of the RDA, for a high bioavailability diet (15\%). Absorption of Fe vary according to the amount of potentiators and inhibitors present in the diet, thus we have 5\%, $10 \%, 12 \%$ or $15 \%$ Fe bioavailability diets. For bioavailability diets of $15 \%$ the RDA for women at childbearing age is $29.4 \mathrm{mg}$ (Institute of Medicine. Food and Nutrition Board, 1997).

It is known that polyphenols have an antioxidant capacity, which is beneficial to prevent oxidative stress, but one of the mechanisms by which they exhibit antioxidant capacity (AOC) is through the property of chelating the transition metals, decreasing their bioavailability. The magnitude of this interaction is different for each polyphenol.

It is extensively studied and quantified in the case of tea, coffee and wine. The fact that iron absorption can be reduced by tea consumption has been recognized for many years, with the inhibitory effects by the marked iron-binding properties of the phenolic compounds bearing catechol groups in tea. It was demostrated that the simultaneous consumption of black tea and iron-containing foods inhibits iron absorption by about 60 to $70 \%$, independently of the strength of the tea. Between-meal tea consumption inhibits non-heme iron absorption by about 20\% (Zijp, Korver \& Tijburg, 2000). It was already proven in 1983 that a cup of coffee reduced iron absorption from a hamburger meal by $39 \%$ as compared to a $64 \%$ decrease with tea (Morck, Lynch \& Cook, 1983).

Although traditional views hold that polyphenols affect nonheme iron absorption only, recent experiments on human intestinal monolayer cells have provided evidence that dietary polyphenolic compounds could interfere with absorption of both heme and nonheme iron across these cells and demonstrated a dose-dependent inhibitory effect of polyphenols on heme iron absorption (Kim, Ham, Shigenaga, \& Han, 2008).

Up to now, no in vivo studies have been conducted on the interaction of yerba mate polyphenols on iron absorption in the diet. The objective of this work was to evaluate the "in vivo" effect of the polyphenols from 
yerba mate infusions, consumed in their traditional form, on the bioavailability of iron and magnesium in the diet.

\section{Materials and Methods}

\subsection{Reagents}

The following reagents were used: Iron (III) Heptahydrate sulfate (Sigma-Aldrich), commercial Kit Architect Ferritin ${ }^{\circledR}$ (Abbot), commercial Kit Architect Iron ${ }^{\circledR}$ (Abbot), commercial Kit Architect Magnesium ${ }^{\circledR}$ (Abbot), commercial Kit Architect Transferrin ${ }^{\circledR}$ (Abbot), Folin-Ciocalteu Reagent (Fluka). Folin-Ciocalteu (Fluka), anhydrous sodium carbonate (Sigma-Aldrich), monohydrate gallic acid (MP Biomedicals, limited liability company (LLC), anticoagulant W (EDTA $0.342 \mathrm{~mol} / \mathrm{L}, \mathrm{pH}$ 7.2) Wiener lab®.

\subsection{Female Volunteers}

The Study Protocol was approved by the Ethics Committee of the Dr. Ramón Madariaga Hospital in Posadas city, Povince of Misiones, Argentina. The tests were carried out with 12 apparently healthy female volunteers after giving their informed consent. Before testing, volunteers were evaluated clinically and with hematology tests. All female volunteers were normal weight, non-smokers, between 20 and 40 years old, they followed a diet which consisted in restricting food high in polyphenols 24 hours before the test and they did not consume vitamin supplements or medicines in the week before the test itself. They went to the laboratory to have the tests done having fasted for 10 to 12 hours on three occasions. On the first occasion they ingested $300 \mathrm{~mL}$ yerba mate infusion; on the second occasion $40 \mathrm{mg}$ of iron (as ferrous sulphate) were dissolved in $300 \mathrm{~mL}$ of water and on the third occasion $40 \mathrm{mg}$ of iron dissolved in $300 \mathrm{~mL}$ of weed infusion were ingested. On each opportunity the nutritional status of iron was evaluated. All tests were performed in the luteal phase of the menstrual cycle to avoid confounding factors with variation in Fe absorption during the menstrual cycle (Chandra, Gupta \&Patel, 2017). In each test, the iron nutritional status of female volunteers was evaluated in order to guarantee that there was no variation in the avidity of Fe absorption. The tests were erythrocyte sedimentation, hemoglobin, hematocrit, serum iron, transferrin, percentage of tranferrin saturation and serum ferritin, as can be seen in Table 1. The tests were performed in no more than two months.

After the first blood sample (time 0 ), the volunteers ingested $300 \mathrm{~mL}$ of yerba mate infusions, ferrous sulfate or yerba mate infusions plus ferrous sulfate at $50{ }^{\circ} \mathrm{C}$ in no more than 5 minutes. They remained seated at a comfortable temperature throughout the study. Blood samples were taken 20,40,50, 60, 80, 100 and 120 minutes after ingestion. They were made by antecubital venipuncture using a catheter. All blood test samples were taken by a trained nurse and under medical supervision. In order to obtain plasma, blood was collected on anticoagulant EDTA (0.342 M, pH 7.2) in the relationship $10 \mu \mathrm{L}$ anticoagulant per blood $\mathrm{mL}$. Plasma separation was performed in a refrigerated centrifuge of $2.500 \mathrm{~g}$ for 10 minutes at $4{ }^{\circ} \mathrm{C}$. All samples were refrigerated and protected from light until the processing time.

Table 1. Hematological parameters of the female volunteers during the 3 tests

\begin{tabular}{|c|c|c|c|c|c|c|c|c|c|c|c|}
\hline & Female volunteer & 1 & 2 & 3 & 4 & 5 & 6 & 7 & 8 & 9 & 10 \\
\hline \multirow{7}{*}{ Test 1: only YM infusión } & GSR 1 & 3 & 5 & 7 & 6 & 6 & 5 & 3 & 9 & 3 & 4 \\
\hline & Hematocrit 2 & 37,7 & 35,5 & 38,7 & 38,6 & 36,5 & 34 & 41,1 & 33,9 & 38,1 & 40,4 \\
\hline & Hemoglobin 3 & 12,8 & 11,9 & 12,7 & 12,3 & 12 & 12 & 13,7 & 11,3 & 12,5 & 13,5 \\
\hline & Serum iron 4 & 74 & 54 & 146 & 65 & 80 & 64 & 100 & 90 & 106 & 49 \\
\hline & Transferrin saturation percentage 5 & 22,2 & 20 & 50,8 & 22 & 26,5 & 19 & 36,1 & 29,9 & 35,7 & 20,5 \\
\hline & Transferrin 6 & 262 & 212 & 226 & 264 & 238 & 256 & 177 & 237 & 234 & 188 \\
\hline & Ferritin 7 & 37,7 & 33 & 28 & 42,5 & 35,3 & 9,6 & 102 & 85 & 15 & 40,5 \\
\hline \multirow[t]{7}{*}{ Test 2: only Fe } & GSR 1 & 9 & 3 & & 7 & 3 & 8 & 6 & 9 & 8 & 10 \\
\hline & Hematocrit 2 & 38,6 & 35,1 & & 38,8 & & 35 & 38,1 & 32,7 & 37,4 & 38,8 \\
\hline & Hemoglobin 3 & 13,2 & 11,8 & & 12,5 & & 12 & 12,1 & 11,5 & 11,8 & 12,7 \\
\hline & Serum iron 4 & 92 & 92 & 138 & 76 & 63 & 59 & 61 & 76 & 70 & 115 \\
\hline & Transferrin saturation percentage 5 & 26,7 & 33,7 & 49,8 & 20,1 & 20,2 & 18 & 52,9 & 27,9 & 21,2 & 43,7 \\
\hline & Transferrin 6 & 271 & 215 & 218 & 298 & 246 & 259 & 218 & 214 & 260 & 207 \\
\hline & Ferritin 7 & 22,1 & 12,1 & 21,5 & 42,1 & 24,4 & 7,6 & 100 & 44,8 & 20,6 & 60 \\
\hline \multirow[t]{7}{*}{ Test 3: YM Infusión YM + Fe } & GSR 1 & 3 & 8 & 3 & 8 & 10 & 9 & 7 & 6 & 3 & 10 \\
\hline & Hematocrit2 & 37,4 & 35,3 & 36,5 & 43,9 & 41 & 35 & 38,5 & 33 & 38,3 & 40,2 \\
\hline & Hemoglobin 3 & 12,4 & 11,9 & 11,9 & 13,9 & 13,4 & 12 & 12,6 & 11 & 12,2 & 12,8 \\
\hline & Serum iron 4 & 117 & 93 & 118 & 126 & 88 & 39 & 90 & 72 & 85 & 142 \\
\hline & Transferrin saturation percentage 5 & 34,7 & 32,4 & 46,1 & 30,1 & 29 & 11 & 37,5 & 26,1 & 27 & 53,2 \\
\hline & Transferrin 6 & 265 & 226 & 198 & 314 & 239 & 275 & 189 & 217 & 248 & 210 \\
\hline & Ferritin 7 & 24,1 & 26,6 & 39,2 & 43,3 & 28,8 & 8 & 78,1 & 47,6 & 15,3 & 83,4 \\
\hline
\end{tabular}

Units and reference values: ${ }^{1}$ Globular sedimentation rate (GSR): $0-15 \mathrm{~mm} / 1 \stackrel{\mathrm{er}}{\mathrm{e}} \mathrm{h} ;{ }^{2}$ Hematocrito: $37-47 \% ;{ }^{3}$ Hemoglobin: 11,5 16, $5 \mathrm{~g} / \mathrm{dL}$; 
${ }^{4}$ Serum iron: $50-170 \mu \mathrm{g} / \mathrm{dL} ;{ }^{5}$ Ferritin: $21,8-276,4 \mathrm{ng} / \mathrm{mL} ;{ }^{6}$ Transferrin: $180-382 \mathrm{mg} / \mathrm{dL} ;{ }^{7}$ Transferrin saturation percentage: $14-31 \%$.

\subsection{Preparation of the Infusion}

The infusion was prepared by a method which simulates a traditional "mateada" (Scipioni, 2010) (Hartwig, Brumovsky \& Fretes, 2012). Briefly, $50 \pm 0.10 \mathrm{~g}$ of yerba mate were placed in a glass beaker, and a stainless steel straw with holes smaller than $0.8 \mathrm{~mm}$, was connected by a silicon hose to a filter flask with a fallopian vacuum. Then approximately $30 \mathrm{~mL}$ of distilled water at $70{ }^{\circ} \mathrm{C}$ were poured, 20 seconds after vacuum was applied for another 20 seconds. Then the vacuum was stopped and a new landfill was made, imitating the traditional pouring. This process was repeated until a volume of $500 \mathrm{~mL}$ was reached. The infusion was ingested immediately after its production.

\subsection{Determination of Total Polyphenols Concentration in the Infusion}

The total polyphenols concentration was determined spectrophotometrically according to ISO 14502-1 (2004) and expressed as g of gallic acid equivalents $/ \mathrm{mL}$ acid infusion $(\mathrm{g} \mathrm{GAE} / \mathrm{mL})$. Briefly, $1.0 \mathrm{~mL}$ of $\mathrm{YM}$ infusion was diluted (1:5) and then diluted (1:100) with distilled water. After that, $1.0 \mathrm{~mL}$ of the latter solution was taken and placed in a test tube. Then, $5.0 \mathrm{~mL}$ of a solution of Folin-Ciocalteu reagent and $4.0 \mathrm{~mL}$ of sodium carbonate solution concentration of 7.5 per cent w/v were added. The tubes were stirred, capped and allowed to stand for 60 minutes at room temperature in the dark before performing the absorbance readings at $765 \mathrm{~nm}$. As reagent blank, $1.0 \mathrm{~mL}$ of diluted infusion was replaced by distilled water.

\subsection{Determination of Serum Magnesium}

A colorimetric method was used to measure serum magnesium. Magnesium forms colored complexes with the arsenazo and its absorbance was measured at $572 \mathrm{~nm}$, being proportional to the concentration of $\mathrm{Mg}$. We worked with an ARCHITECT c-Systems 8000 analyzer and with the commercial kit for the determination of the brand Magnesium ABBOTT. The detection limit of the method is $0.152 \mathrm{mgMg} / \mathrm{dL}$ and the limit of quantification is $0.66 \mathrm{mg} \mathrm{Mg} / \mathrm{dL}$.

\subsection{Determination of Magnesium of Yerba Mate Infusion}

Determination of the magnesium of yerba mate infusion has been measured with 200.2 EPA 600 / R-94. Briefly, an amount of $100 \mathrm{~mL}$ of the infusion is taken and placed in a tared crucible, then in a convection oven at $105^{\circ} \mathrm{C}$ to dryness (about 16 hours), then it is removed from the furnace, cooled in a desiccator, weighed and placed in a muffle at $550^{\circ} \mathrm{C}$ for $6 \mathrm{~h}$ to convert the sample to ashes. A dilution is then carried out where the final volume has a concentration of $0.1 \%$ lanthanum ( $\mathrm{La} 2 \mathrm{O} 3$ ) to improve the readings a PerKin Elmer AAnalyst 700 in flame mode (Air-Acetylene), with hollow cathode lamp Ca-Mg was used. The detection limit of the method is $0.1 \mathrm{mg}$ $\mathrm{Mg} / \mathrm{L}$ and the limit of quantification is $0.20 \mathrm{mg} \mathrm{Mg} / \mathrm{L}$.

\subsection{Determination of Serumc Iron}

A direct colorimetric method (Ferene-S* reagent) was used to determine serum iron without deproteinization. We work with an ARCHITECT c-Systems 8000 analyzer. At pH 4.8, iron is released from transferrin to which it is bound and then quantitatively reduced to a ferric state. Iron forms with the Ferene-S reagent, forms a stable color complex whose color intensity is proportional to the amount of iron in the sample. We work with the ABBOTT commercial iron determination kit. The detection limit of the method is $1.3 \mu \mathrm{g} \mathrm{Fe} / \mathrm{dL}$ and the limit of quantification is $5.4 \mathrm{\mu g} \mathrm{Fe} / \mathrm{dL}$.

\subsection{Determination of Iron of Yerba Mate Infusion}

The determination of Fe in the infusions was performed using the 200.2 EPA 600 / R-94 method. In a tared crucible, $100 \mathrm{~mL}$ of the convection stove infusion is carried to dryness at $105^{\circ} \mathrm{C}$. Then it is cooled in a desiccator and weighed. After that, it is carried to $550^{\circ} \mathrm{C}$ in a muffle for 6 hours to obtain ashes. They are brought to $100 \mathrm{~mL}$ with $10 \% \mathrm{HCl}$. The Fe concentration of this solution was determined with a Perkin Elmer Atomic Absorption Unit, Model AAnalyst 700 Spectrometer in flame (air-acetylene) mode with hollow cathode lamp. The detection limit of the method is $0.02 \mathrm{mg} \mathrm{Fe} / \mathrm{L}$ and the limit of quantification is $0.04 \mathrm{mg} \mathrm{Fe} / \mathrm{L}$.

\subsection{Calculation of Magnesium and Iron Absortion}

To calculate the magnesium and iron percentage absorbed by each female volunteer, we determined the body surface area "S" (Farah, Monteiro, Donangelo \& Lafay, 2008) and then we calculated the needed "PV" plasma volume (García Curiel, \& Gómez Perales, 2001) as Formulae 1. 


$$
S=\frac{\left(\text { Weight }^{0,425} \times \text { Height }^{0,725}\right) \times 71,84}{10000}
$$

Weight is expressed in $\mathrm{kg}$, height in $\mathrm{cm}$ and the surface in $\mathrm{m}^{2}$. Plasma volume, expressed in $\mathrm{mL}$, was calculated by the following 2 and 3Formulaes 2 and 3. Table 2 shows the anthropometric parameters of the 12 female volunteers:

$$
\begin{gathered}
P V_{\text {men }}=1578 \times S \\
P V_{\text {women }}=1395 \times S
\end{gathered}
$$

The total amount of polyphenols absorbed by each volunteer was determined by calculating the "area under the curve" with the method of the sum of the areas of the rectangles (base $\mathrm{x}$ height) in the absorption versus time charts (data not shown) according to Formulae 4:

$$
A=\Delta x \sum H_{i}
$$

Table 2. Anthropometrics parameters of the female volunteers

\begin{tabular}{|l|l|l|l|l|l|l|l|l|l|l|l|l|}
\hline Volunteer & $\mathbf{1}$ & $\mathbf{2}$ & $\mathbf{3}$ & $\mathbf{4}$ & $\mathbf{5}$ & $\mathbf{6}$ & $\mathbf{7}$ & $\mathbf{8}$ & $\mathbf{9}$ & $\mathbf{1 0}$ & $\mathbf{1 1}$ & $\mathbf{1 2}$ \\
\hline Weight $\mathbf{( k g )}$ & 65,5 & 67 & 70 & 53,4 & 65 & 75 & 60,9 & 65 & 56 & 77 & 65 & 74 \\
\hline Height (cm) & 169,5 & 167 & 164 & 153 & 159 & 157 & 170 & 163 & 158 & 167 & 164 & 176 \\
\hline
\end{tabular}

Where $\mathrm{H}_{\mathrm{i}}$ is the average height of each rectangle and $\Delta \mathrm{x}_{\mathrm{i}}$ is the rectangle base it is the time lapse between each test and obtaining the amount absorbed per liter of plasma and multiplying it by the VP.

Calculating the mineral (magnesium or iron) absorption percentage as follows as can be see in Formulae 5:

$$
\% \_ \text {Mineral__absorbed }=\frac{\text { Mineral_absorbed }}{\text { Mineral_ingested }} \times 100
$$

\subsection{Statistical Analysis}

Data were expressed as the means \pm standard deviations (SD). The data were submitted for analysis of variance (ANOVA). Differences between the groups were considered significant when $p \leq .05$. To compare the means, the Student test was used. To analyze the relationship between different absorption profilest linear regression was used. To analyze the variation within each absorption profiles paired samples was used. The statistical program Statgraphics Centurion XVI Plus was used.

\section{Results}

\subsection{Characterization of Ingested Yerba Mate Infusion}

It worked with two different lots of the same brand of elaborate yerba mate. For the magnesium bioavailability study it worked with 12 female volunteers, of which only 10 participated of the iron bioavailability study. The first half of female volunteers consumed the infusions of the first batch of yerba mate and the second half consumed the other yerba mate infusions lot. Differences were observed in the composition of the infusions. Thus, the first female volunteers ( 6 of magnesium bioavailability study and 5 of iron bioavailability study) ingested $300 \mathrm{~mL}$ of an infusion of yerba mate equivalent to 10 mates poured contained $50.8 \pm 6.2 \mathrm{mg}$ of $\mathrm{Mg}, 325$ $\pm 18.7 \mu \mathrm{g}$ of $\mathrm{Fe}$ and $1.52 \pm 0.04 \mathrm{~g} \mathrm{GAE}$ of total polyphenols, while the last female volunteers ingested $300 \mathrm{~mL}$ of the yerba mate infusion containing $105 \pm 9.1 \mathrm{mg}$ of $\mathrm{Mg}, 426 \pm 49 \mu \mathrm{g}$ of Fe and $1.36 \pm 0.09 \mathrm{~g} \mathrm{GAE}$ of total polyphenols.

\subsection{Average Profile of Magnesium Absorption in Serum}

The volunteers were divided into two groups, according to the amount of $\mathrm{Mg}$ ingested, corresponding Group 1 (G1) to female volunteers 1 to 6 and Group 2 (G2) which corresponds to female volunteers 7 to 12 . It was determined that there were no statistically significant differences in the amount of $\mathrm{Mg}$ absorbed between the two groups ( $\mathrm{p}<0.419718$ ), being the average absorption in $\mathrm{t} 1 \mathrm{of} 3.4 \pm 1.6 \mathrm{mg}$ of $\mathrm{Mg}$ and in the $\mathrm{G} 2 \mathrm{of} 2.9 \pm 0.8 \mathrm{mg}$ 
$\mathrm{Mg}$ the $\mathrm{Mg}$.

These values indicate that, in spite of the fact that the amount of Mg ingested was doubled in the different intakes, the amount absorbed by the body keeps constant and with an average of $3.1 \pm 1.2 \mathrm{mg}$ of $\mathrm{Mg}$.

When analyzing the 12 individual profiles (data not shown), it was observed that $40 \%$ of the female volunteers, started to increase the serum $\mathrm{Mg}$ values after 20 minutes of the yerba mate infusion intake as can be seen in Figure 1.

According to the results, in $300 \mathrm{~mL}$ of Yerba Mate infusions, we have an average of $77.9 \pm 29.5 \mathrm{mg}$ of $\mathrm{Mg}$ in solution with an average of $1.290 \mathrm{mg}$ EAG of polyphenols which have the ability of chelating metals, so it can be assumed that the polyphenols could be chelating the $\mathrm{Mg}$, decreasing its average absorption to only $3.1 \mathrm{mg}$ $\mathrm{Mg}$.

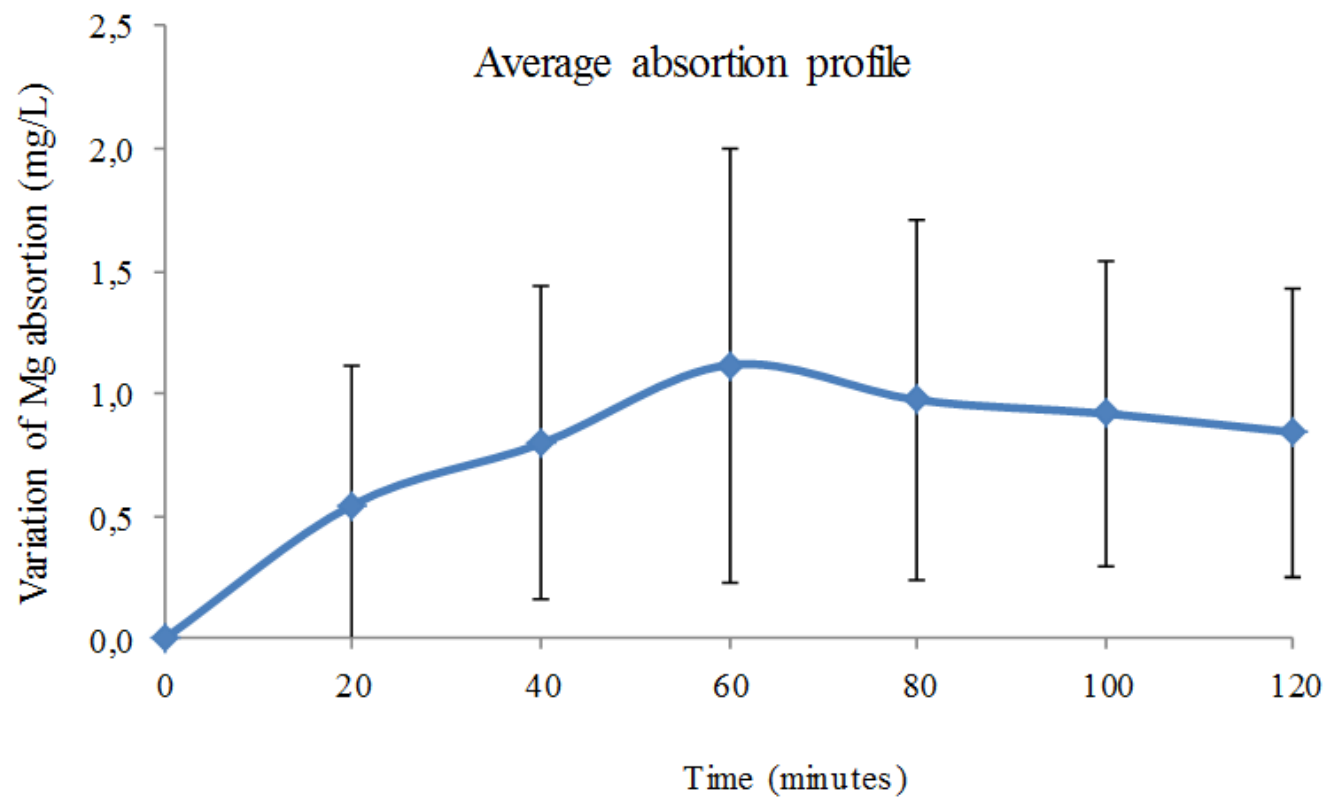

Figure 1. Variation of magnesium absortion (mean $\pm \mathrm{SD}$ ) of the 12 female volunteers.

\subsection{Iron Absorption Serum Profiles}

It was observed in the iron absorption profiles of the 10 female volunteers (dates not shown) a great interindividual variability in the iron absorption capacity. When comparing the ferrous sulphate absorption profiles to those of iron consumed along with the yerba mate infusions (ferrous sulfate + YM Fe), a decrease of the ferrous sulfate absorption was observed in all the volunteers profiles (data not shown).

A hypothesis test of paired samples $(\alpha \leq 0.05)$ was used for the iron absorption profiles. It was observed that there are significant differences between the yerba mate iron absorption profile and the profile of the absorption of iron sulphate plus iron of yerba mate infusion of $\left(\mathrm{P} \leq 10^{-7}\right)$ and also between iron of yerba mate absorption profiles and iron of ferrous sulfate absorption profile $(\mathrm{P} \leq 0.012)$. It was also determined that there are significant differences between absorption profile of iron absorption of ferrous sulphate and the iron absorption profile of ferrous sulphate plus iron from the yerba mate infusion $\left(\mathrm{P} \leq 10^{-7}\right)$ as can be seen in Figure 2 . 


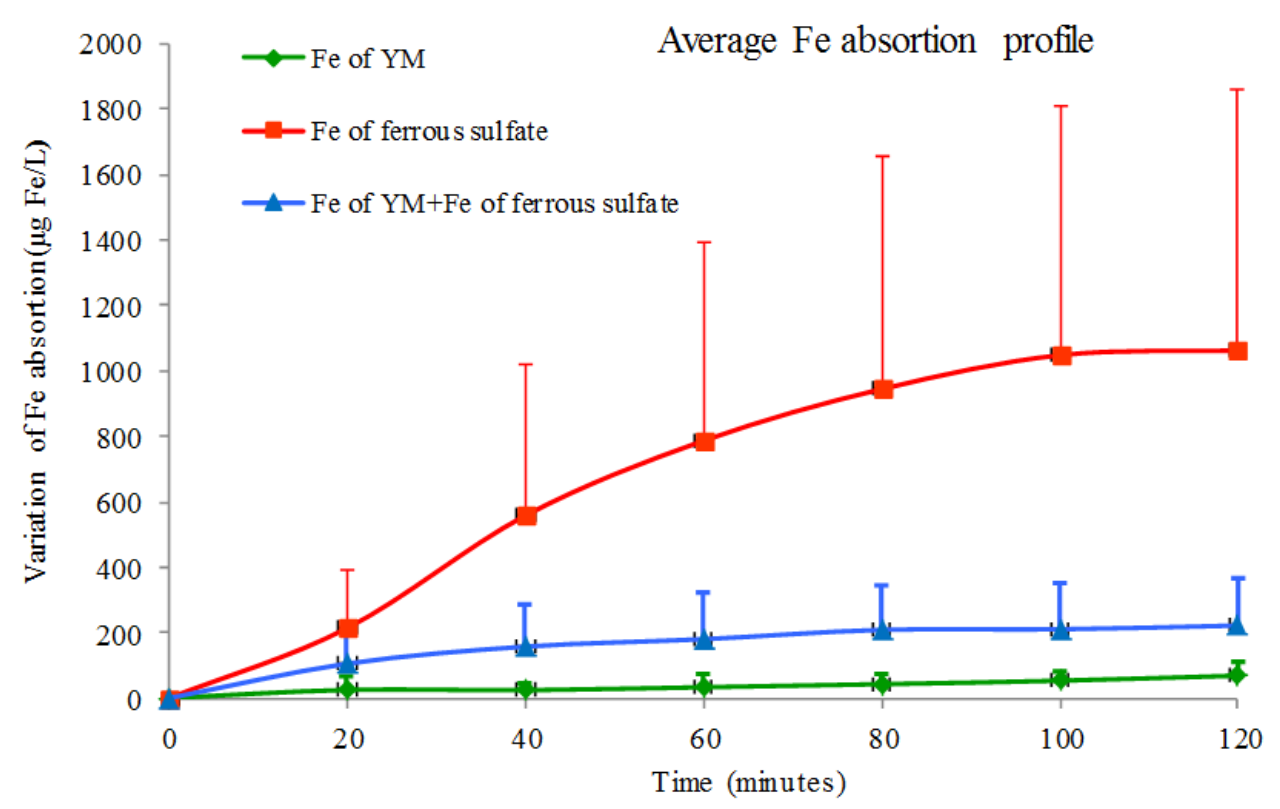

Figure 2. Average Fe absortion profile (mean $+\mathrm{SD}$ ) of serum iron absorbed by 10 female volunteers in different consumption forms

To identify the mean moment at which the global change in iron absorption was detected, the Fisher's Minimum Difference (LSD) was used with $95.0 \%$ confidence level. It was verified that at 40 minutes of the ingestion of yerba mate infusion an increase in iron absorption began to be detected. In the case of the intake of the $40 \mathrm{mg}$ of iron consumed as ferrous sulfate, the absorption began to be detected after 20 minutes of the intake. When yerba mate infusion with the ferrous sulfate was ingested, it was observed that iron absorption is detected at 25 minutes of the acute intake.

\subsection{Effect of Polyphenols on Iron Absorption}

It was determined that the yerba mate infusions contribute on average $376 \pm 21 \mu \mathrm{g}$ of $\mathrm{Fe}$, taking into account the individual absortions of each of the female volunteers, the average absorption percentage of iron from the 300 $\mathrm{mL}$ of yerba mate infusion is $44.6 \pm 18.4 \%$ an average of $173 \pm 20 \mu \mathrm{g}$ de Fe.

When the volunteers consumed $40000 \mu \mathrm{g}$ of $\mathrm{Fe}$ in ferrous sulfate form it was observed that only $3310 \mu \mathrm{g}$ de $\mathrm{Fe}$ is absorbed on average $8.3 \pm 6.1 \%$ of iron total intake of $40 \mathrm{mg}$ Fe. When ingested these $40 \mathrm{mg}$ of Fe together with $300 \mathrm{~mL}$ of the yerba mate infusion, Fe absorption decreased to $803 \mu \mathrm{g}$ of Fe and $2.0 \pm 1.3 \%$ of iron total intake of $40426 \mathrm{mg} \mathrm{Fe}$, as seen in Figure 3.

If we take the absorbed amount when $40 \mathrm{mg}$ of Fe were consumed as the maximum each volunteer can absorb, and we compare it with the amount of ferrum absorbed when digesting the $40 \mathrm{mg}$ of $\mathrm{Fe}$ and the $300 \mathrm{~mL}$ of the yerba mate infusion together, we will get the percentage of the ferrum absorption. . The average absorption of Fe is $26.6 \pm 10 \%$, being so the average decrease in the bioavailability of Fe of $73.2 \pm 10$. 


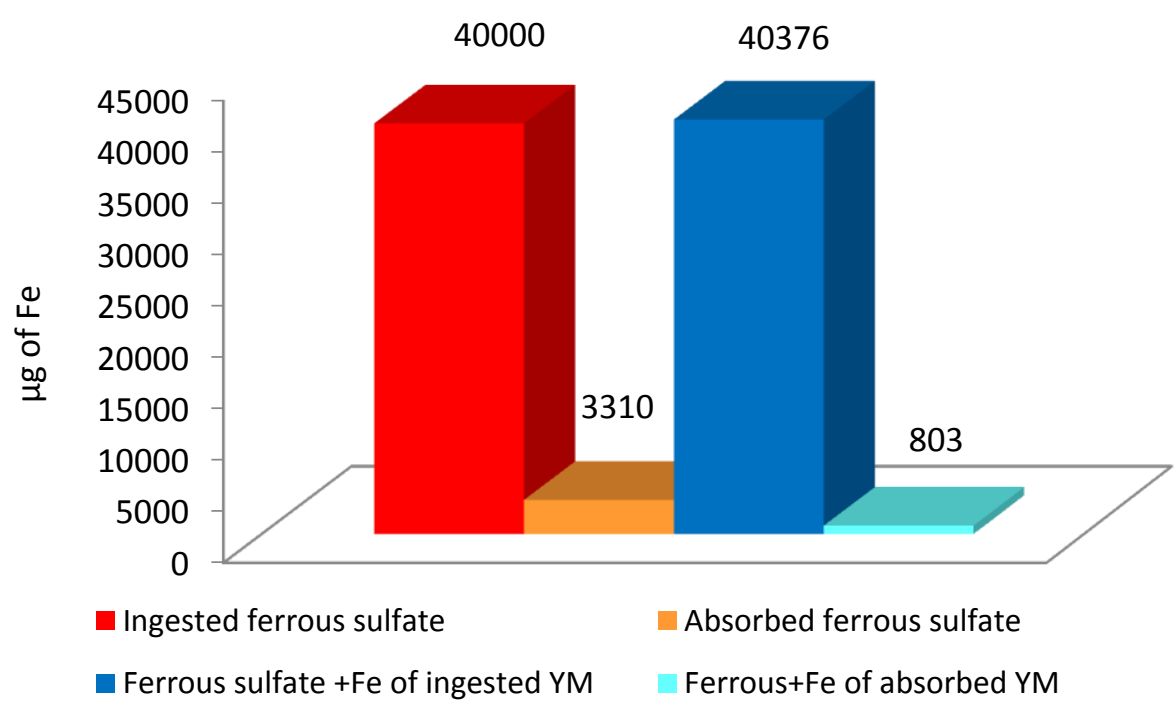

Figure 3. Inhibition of the bioavailability of Fe by action of the polyphenols from yerba mate infusions

\section{Discussion}

The elaborated yerba mate is a heterogeneous product, constituted by a mixture of leaf and stick. The yerba mate harvest extends for a period of 6 months from April (zafra) to September (zafriña), when sprouting begins. Like any agricultural product, its chemical composition can vary with the type of soil, climate, time of year, age of the plant and the leaves and genetic characteristics. Significant differences are reported in the content of minerals (N, $\mathrm{P}, \mathrm{Ca}$ and $\mathrm{Mg}$ ) in yerba leaves from different places. In Brazil there is a higher content of polyphenols and lower mineral content in yerba mate extracts from plants that grow exposed to sunlight (typical yerba mate) compared to those that grow in the shade (native plantations). (Escalada, Brumovsky, Hatwig, 2011)(Oliva, Reissmann, Gaiad, Sturion, De olivera, Wisnewiski \&Miaqui, 2006). It was observed that caffeine varied significantly with the harvest time, being lower in the sprouting months and increasing as the leaves mature. (Heck; Schmalko \& Gonzalez de Mejia, 2008).

It was found that in the leaves of 9-year-old yerba trees the amount of $\mathrm{P}, \mathrm{Mg}, \mathrm{Ca}$ was greater in the zafriña period than in the zafra, while in the 12-year-old plants those same minerals were found in greater quantity, both in the zafra and in the zafriña the concentration of Fe in young leaves was varied between 62 and $109 \mathrm{mg} \mathrm{kg-1}$, not finding a statistically significant difference with the mature leaves, with values between 85 and $102 \mathrm{mg} \mathrm{kg}$. Some authors also indicate that there is variation in $\mathrm{Fe}$ and $\mathrm{Mg}$ content of yerba in relation to the progeny to which they belong. (Jacques, Arruda, De Oliveira, De Oliveira, Dariva, De Oliveira \& Carama, 2007).

We have found there is a great variability in $\mathrm{Mg}$ composition in yerba mate infusions between $50.8 \pm 6.2$ and 105 $\pm 9.1 \mathrm{mg}$ of Mg every $300 \mathrm{~mL}$ of yerba mate infusions (49\% of variation). This agrees with the values (reported by some authors) of $188 \mathrm{mg}$ of $\mathrm{Mg} / \mathrm{L}$ de infusion with a variation between 168 and $200 \mathrm{mg}$ of $\mathrm{Mg} / \mathrm{L}$, corresponding to an average of $56.4 \mathrm{mg}$ of $\mathrm{Mg}$ every $300 \mathrm{~mL}$ (Heinrichs \& Malavolta, 2001) and others informed values of $129 \pm 42 \mathrm{mg}$ every $500 \mathrm{~mL}$ of infusion, corresponding to $77.4 \mathrm{mg} \mathrm{Mg}$ in $300 \mathrm{~mL}$ (Maiocchi et al., 2016). These variations could be due to the yerba mate mineral composition varied according to the place of development of plantations (Faria et al., 2008; Bastos et al., 2014) and that the leaves mineral contents drastically change depending on agricultural practices. The fertilizers and soil type have a significant impact on leaf mineral composition (Helena et al., 2007).

While the queantities of $\mathrm{Mg}$ of the infusions consumed by the volunteers were diferent, with values of $50.8 \pm 6.2$ $\mathrm{mg}$ of $\mathrm{Mg}$ and 50.8 and $105 \pm 9.1 \mathrm{mg}$ of $\mathrm{Mg}$, the quantities absorbed were not statistically different with an average of 3,1 $\pm 1.2 \mathrm{mg}$ of $\mathrm{Mg}$. This value corresponds to an absorption of $7.0 \pm 3.7 \%$ and $2.8 \pm 0.75 \%$ of the $\mathrm{Mg}$ ingested from the first and second infusions respectively. This absorbed amount of $\mathrm{Mg}$ constitutes $1 \%$ of the RDA. These values of percentage of absorption contrast with those provided by other authors that indicate an absorption efficiency of 50\% of the Mg present in solid diets (Coudray, Demigne \&Rayssiguier, 2003) and of 80 - 90\% of breast milk and about 55-75\% in formulated milk contains according to the World Health Organization (2004). 
There is currently no data on the in vivo absorption of $\mathrm{Mg}$ from yerba mate infusions, it contain on average 77.9 $\pm 29.5 \mathrm{mg}$ of $\mathrm{Mg}$ and $1.41 \pm 0.16 \mathrm{mg}$ of EAG of polyphenols. Due to the fact that polyphenols have the ability to chelate metals, they are the most likely cause of the low absorption Mg values found in yerba mate infusions.

In the case of Fe content, it can be observed that there was also a statistically significant difference between both infusions, but with a much lower variability of $23.7 \%$ regarding $\mathrm{Mg}$ variability. Many authors have described in vivo and in vitro polyphenols interaction from various sources on iron absorption, which varies according to the chemical structure of polyphenol. Contrary, some polyphenols have no inhibitory effect on Fe uptake; it is so that, small amounts of grapefruit polyphenols in diets can improve availability of some minerals without significant negative influence on Fe status (Frejnagel, Gomez-villalva, Urbano \& Zduñczyk, 2003). Some authors have reported up to $90 \%$ Fe absorption inhibition in Leucaena glauca leaf in Thailand (Mascitelli \& Goldstein, 2013). It was also observed that among elderly participants in Framingham Heart study, a cup of coffee $(236 \mathrm{~mL})$ consumed for one week was associated with a $1 \%$ decrease in serum ferritin (Petry, Egli, Zeder, Walczyk \&Hurrell, 2010). There are data that show that bioactive dietary polyphenols inhibit also heme iron absorption mainly by reducing basolateral iron exit rather than decreasing apical heme iron uptake in intestinal cells (Ma et al., 2010).

On the other hand even some authors have concluded that diets rich in polyphenols may be beneficial for iron overload patients by limiting the rate of intestinal absorption (Lesjak et al., 2014). Polyphenols are linked to iron through the ortho-dihydroxy (catechol) or trihydroxybenzene group (Khokhar \& Owusu Apenten, 2003) doing by this mechanism, antibacterial activity due to its strong affinity with iron (Daglia, 2012).

Some authors compared the yerba mate chelation power according to their origin, determining that Brazilian and Uruguayan yerba mates had an $80 \%$ iron chelation capacity, while the Argentinian yerba mate's iron chelation capacity was lower but still significant (Colpo et al. 2016). Other authors showed that mate tea and green tea extracts provoke a very significant inhibition of the iron absorption, whereas it is much less significant with red wine extract (Anghileri \&Thouvenot, 2000).

There are no in vivo studies about the inhibitory power of yerba mate polyphenols on iron absorption. In this study it was found that by ingesting $40 \mathrm{mg}$ of $\mathrm{Fe}$ as ferrous sulphate (100\%), $8.3 \pm 6.1 \%$ of $\mathrm{Fe}$ was absorbed, while if it is consumed with $300 \mathrm{~mL}$ of yerba mate infusion, containing on average $1.41 \pm 0.16 \mathrm{mg}$ GAE of polyphenols, the Fe absorption decreases to $2.0 \pm 1.3 \%$.

Thus, the polyphenols could be responsible for the decrease in absorption of iron contained in yerba mate infusions. Therefore, the bioavailability of Fe decreased by $73.2 \pm 10 \%$, reaching its absorption only $26.8 \pm 10 \%$ with respect to $\mathrm{Fe}$ ingested without polyphenols, as can be seen in Figures 3.

Due to the high prevalence of iron deficiency anaemia in women of childbearing age in addition to the decrease in absorption of Fe produced by polyphenols is that some authors evaluate the way to neutralize this inhibitory effect. The action of ascorbic acid and Ethylenediaminetetraacetic acid was studied. Ascorbic acid was found to be more efficient than Ethylenediaminetetraacetic in a way that lesser quantity is required for completely overcoming negative iron binding effects of polyphenols and similar samples (Tamilmani \& Pandey, 2016).

In Argentina there is a habit of consuming yerba mate infusion throughout the day, including before and after meals.

To avoid the inhibitory effect of the polyphenols on the iron absortion from diet, it would be advisable to consume yerba mate infusion at least one hour before and 1.5 hours after the food intake.

\section{Conclusions}

It was determined that $300 \mathrm{~mL}$ of yerba mate infusions contain an average the $3.1 \pm 1,2 \mathrm{mg}$ de $\mathrm{Mg}, 376 \pm 21 \mu \mathrm{g}$ of Fe and $1.41 \pm 0.16 \mathrm{mg} \mathrm{GAE}$ of polyphenol.

YM infusions contain 25\% of the RDI for women of childbearing age, but only Mg amounts representing $1 \%$ of the RDI can be absorbed.

It was verified that absorption dynamics present a great interindividual variability, observing that $42 \%$ of the population begins to absorb magnesium after 20 minutes of acute intake.

It was determined that the $44.6 \pm 18.4 \%$ of the iron ingested was absorbed when consuming $300 \mathrm{~mL}$ of yerba mate infusion during the two hours the test lasted, constituting approximately $1 \%$ of RDA for women at childbearing age and with a diet of high iron bioavailability of $15 \%$.

It was determined that, out of $40 \mathrm{mg}$ of $\mathrm{Fe}$ ingested as ferrous sulphate $8.3 \pm 6.1 \%$ of $\mathrm{Fe}$ a was absorbed, while when consuming it with $300 \mathrm{~mL}$ of yerba mate infusion, containing on average $1.41 \pm 0.16 \mathrm{mg}$ GAE of 
polyphenols, Fe absorption decreased to $2.0 \pm 1.3 \%$ of the initial intake.

It can be concluded that yerba mate infusions prepared in their traditional form of hot mate have a nonheminic iron absorption inhibitory effect of $73.2 \pm 10 \%$.

Due to the prevalence of iron deficiency anaemia in women at childbearing age and Fe absorption inhibitory effect by the polyphenols of hot yerba mate infusions, it is important to advise their consumption away from meals, as well as tea and coffee infusions.

\section{Acknowledgments}

The authors are grateful to the National Yerba Mate Institute (INYM) for the support received from the Foundation for Scientific and Technological Research and Development (DINCYT) for the use of its equipment and laboratories and especially the volunteers who participated in the study for his patient collaboration.

\section{References}

Anghileri, L. J., \& Thouvenot, P. (2000). Natural Polyphenols-Iron Interaction: Its Biological Importance, Biological Trace Element Research, 73(3), 251-258. https://doi.org/10.1385/BTER:73:3:251.

Barbagallo, M., \& Dominguez, L. J. (2007). Magnesium metabolism in type 2 diabetes mellitus, metabolic syndrome and insulin resistance, Archives of Biochemistry and Biophysics, 458(1), 40-47. https://doi.org/10.1016/j.abb.2006.05.007.

Bastos, M. C., Reissmann, C. B., Keseker, J. F., Pauletti, V., Gaiad, S., \& Sturion, J. A. (2014). Mineral content of young leaves of yerba mate, Pesquisa Florestal Brasileira, 34(77), 63-71. https://doi.org/10.4336/2014.pfb.34.77.594.

Belluci, M. M., Schoenmaker, T., Rossa-Junior, C., Orrico, S. R., de Vries, T. J., \& Everts, V. (2013). Magnesium deficiency results in an increased formation of osteoclasts, The Journal of nutritional biochemistry. Elsevier Inc., 24(8), 1488-98. https://doi.org/10.1016/j.jnutbio.2012.12.008.

Bracesco, N., Sanchez, A. G., Contreras, V., Menini, T., \& Gugliucci, A. (2011). Recent advances on Ilex paraguariensis research: Minireview, Journal of Ethnopharmacology, 136(3), 378-384. https://doi.org/10.1016/j.jep.2010.06.032.

Bravo, L., Goya, L., \& Lecumberri, E. (2007). LC/MS characterization of phenolic constituents of mate (Ilex paraguariensis, St. Hil.) and its antioxidant activity compared to commonly consumed beverages, Food Research International, 40(3), 393-405. https://doi.org/10.1016/j.foodres.2006.10.016.

Broillet, A., \& Wermeille, M. (1983). in Man Following Oral Administration, 13(5), $279-286$.

Brun, L. R., Brance, M. L., Lombarte, M., Maher, M. C., Di Loreto, V. E., \& Rigalli, A. (2015). Effects of Yerba Mate (IIex paraguariensis) on Histomorphometry, Biomechanics, and Densitometry on Bones in the Rat, Calcified Tissue International. Springer US, 97(5), 527-534. https://doi.org/10.1007/s00223-015-0043-0.

Camaschella, C. (2015). Iron-Deficiency Anemia, New England Journal of Medicine, 372(19), 1832-1843. https://doi.org/10.1056/NEJMra1401038.

Chandra, S., Gupta, N., \& Patel, S. K. (2017). Study of iron status indicators in different phases of menstrual cycle in first year medical college females, 5(1), 46-49.

Colpo, A. C., Rosa, H., Lima, M. E., Pazzini, C. E. F., De Camargo, V. B., Bassante, F. E. M., ... Folmer, V. (2016). Yerba mate (Ilex paraguariensis St. Hill.)-based beverages: How successive extraction influences the extract composition and its capacity to chelate iron and scavenge free radicals, Food Chemistry. Elsevier Ltd, 209, 185-195. https://doi.org/10.1016/j.foodchem.2016.04.059.

Conforti, A. S., Gallo, M. E., \& Saraví, F. D. (2012). Yerba Mate (Ilex paraguariensis) consumption is associated with higher bone mineral density in postmenopausal women, Bone. Elsevier Inc., 50(1), 9-13. https://doi.org/10.1016/j.bone.2011.08.029.

Coudray, C., Demigne, C., \& Yves Rayssiguier, Y. (2003). Recent Advances in Nutritional Sciences Effects of Dietary Fibers on and Humans 1. (October 2002), 22-25.

Critical Reviews in Food Science and Nutrition, 40(5), 371-398. https://doi.org/10.1080/10408690091189194

Daglia, M. (2012). Polyphenols as antimicrobial agents, Current Opinion in Biotechnology. Elsevier Ltd, 23(2), 174-181. https://doi.org/10.1016/j.copbio.2011.08.007.

De Baaij, J. H., Hoenderop, J. G., \& Bindels, R. J. (2015). Magnesium in man: implications for health and 
disease, Physiol Rev, 95(1), 1-46. https://doi.org/10.1152/physrev.00012.2014.

Durante, I., Da, E., Goularte, F. L., \& Ribani, M. (2010). Artigo, Química Nova, 33(1), 119-123.

Escalada, G., Brumovsky, L. A., \& Hartwi, V. G. (2011). Effects of growing and processing location on polyphenol content and antioxidant capacity of yerba mate (Ilex paraguariensis), Revista Cienciencia y Tecnología, 13(15), 66-74

Farah, A., Monteiro, M., Donangelo, C. M., \& Lafay, S. (2008). Chlorogenic Acids from Green Coffee Extract are Highly Bioavailable in Humans. The Journal of Nutrition Biochemical, Molecular, and Genetic Mechanisms, (September), 2309-23015. https://doi.org/10.3945/jn.108.095554.

Faria, A., Pestana, D., Monteiro, R., Oliveira, J., Freitas, V. de, Azevedo, I., Calhau, C., \& Mateus, N. (2008). Influence of anthocyanins and derivative pigments from blueberry (Vaccinium myrtillus) extracts on MPP+ intestinal uptake: A structure-activity approach, Food Chemistry, 109(3), 587-594. https://doi.org/10.1016/j.foodchem.2008.01.009.

Francisco, Á. L. M. De \& Rodríguez, M. (2013). Magnesio y enfermedad renal crónica, 389-399. https://doi.org/10.3265/Nefrolog.

Frejnagel, S. S., Gomez-villalva, E., Urbano, G., \& Zduñczyk, Z. (2003). The Influence of Grapefruit Phenolic Compounds on Mineral Absorption in Rats, 12, 137-140.

García Curiel, A., \& Gómez Perales, J. L. (2001). Cálculo de las volemias mediante dilución isotópica. Revisión teórica y práctica, Revista Española de Medicina Nuclear, 20(6), 466-472.

Gatto, E. M., Melcon, C., Parisi, V. L., Bartoloni, L. \& Gonzalez, C. D. (2015). Inverse association between yerba mate consumption and idiopathic Parkinson's disease. A case-control study, Journal of the Neurological Sciences, 356(1-2). https://doi.org/10.1016/j.jns.2015.06.043.

Hallberg, L., \& Hulthén, L. (2000). Prediction of dietary iron absorption an algorithm for calculating absorption and bioavailability.pdf, American Journal of Clinical Nutrition, 71, 1147-1160. Available at: http://ajcn.nutrition.org/content/71/5/1147.long

Hartwig, G. V., Brumovsky, A. L., \& Raquel, Fretes, M. (2012). A Total Polyphenol Content of Mate (Ilex paraguariensis) and Other Plants-derived Beverages, Journal of Food Research, 1(3), 58-67. https://doi.org/10.5539/jfr.v1n3p58.

Heck, C. I., Schmalko, M., \& De Mejia, E. G. (2008). Effect of growing and drying conditions on the phenolic composition of Mate teas (Ilex paraguariensis), Journal of Agricultural and Food Chemistry, 56(18), 8394-8403. https://doi.org/10.1021/jf801748s

Helena, D., Bastos, M., Moura, D., Ruth, D. O., Teixeira, L., Patrícia, M., Carvalho, D. O., \& Lima, M. (2007). Yerba mate: Pharmacological Properties, Research and Biotechnology. Medicinal and Aromatic Plant Science and Biotechnology, 1(1), 37-46

Institute of Medicine (IOM). (1997). Food and Nutrition Board. Dietary Reference Intakes: Calcium, Phosphorus, Magnesium, Vitamin D and Fluorideexternal link disclaimer. Washington, DC: National Academy Press. https://www.ncbi.nlm.nih.gov/books/NBK225472/

Jacques, R., Arruda, E., De Oliveira, L. C. S., De Oliveira, A. P., Dariva, C., De Oliveira, J. V., \& Carama, E. B. (2007). Influence of agronomic variables on the macronutrient and micronutrient contents and thermal behavior of mate tea leaves (Ilex paraguariensis). Journal of Agricultural and Food Chemistry, 55, $7510-7516$.

Khokhar, S., \& Owusu Apenten, R. K. (2003). Iron binding characteristics of phenolic compounds: Some tentative structure-activity relations, Food Chemistry, 81(1), 133-140. https://doi.org/10.1016/S0308-8146(02)00394-1.

Kim, E. Y., Ham, S. K., Shigenaga, M. K., \& Han, O. (2011). Bioactive dietary polyphenolic compounds reduce nonheme iron transport across human intestinal cell monolayers. J. Nutr., 138, 1647-1651.

Kogan, L., Abeyá Gilardón, E., \& Biglieri, A. (2008). Anemia: La desnutrición oculta. ENNyEncuesta Nacional de Nutrición y Salud. Ministerio de Salud Pública de la Argentina. Presidencia de la Nación.

Lesjak, M., Hoque, R., Balesaria, S., Skinner, V., Debnam, E. S., Srai, S. K. S., \& Sharp, P. A. (2014). Quercetin inhibits intestinal iron absorption and ferroportin transporter expression in vivo and in vitro, PLoS ONE, 9(7), 1-11. https://doi.org/10.1371/journal.pone.0102900. 
Lückemeyer, D. D., Müller, V. D. M., Moritz, M. I. G., Stoco, P. H., Eloir, P., Schenkel, P. H. E., Barardi, C. R. M., Flávio, H., Reginatto, F. H., \& Simões, C. O. M. (2012). Effects of Ilex paraguariensis A. St. Hil.(Yerba Mate) on Herpes Simplex Virus Types 1 and 2 Replication. Phytotheapyr Researh, 26, 535-540. https://doi.org/10.1002/ptr.3590.

Ma, Q., Eun-young Kim \& Han, O. (2010). Bioactive Dietary Polyphenols Decrease Heme Iron Absorption by Decreasing Basolateral Iron Release in Human Intestinal Caco-2 Cells 1, 2. The journal of nutrition, 1117-21.

Maiocchi, M. G., Del Vitto, L. A., Petenatti, M. E., Marchevsky, E. J., Avanza, M. V., Pellerano, R. G., \& Petenatti, E. M. (2016). Multielemental composition and nutritional value of "dumosa" (Ilex dumosa), "yerba mate" (Ilex paraguariensis) and their commercial mixture in different forms of use. Revista de La Facultad de Ciencias Agrarias, 48(1), 145-159.

http://www.scielo.org.ar/scielo.php?script=sci_arttext\&pid=S1853-86652016000100011\&lng=es\&nrm=iso

Mascitelli, L., \& Goldstein, M. R. (2013). Inhibition of Iron Absorption by Polyphenols as an Anticancer Mechanism, Polyphenols in Human Health and Disease, 2(December 2010), 1283-1286. https://doi.org/10.1016/B978-0-12-398456-2.00097-9.

Mezadri, T., Villaño, D., Fernández-Pachón, M. S., García-Parrilla, M. C., \& Troncoso, A. M. (2008). Antioxidant compounds and antioxidant activity in acerola (Malpighia emarginata DC.) fruits and derivatives, Journal of Food Composition and Analysis, 21(4), 282-290. https://doi.org/10.1016/j.jfca.2008.02.002.

Petry, N., Egli, I., Zeder, C., Walczyk, T., \& Hurrell, R. (2010). Polyphenols and phytic acid contribute to the low iron bioavailability from common beans in young women, The Journal of nutrition, 140(11), 1977-1982. https://doi.org/10.3945/jn.110.125369.

Oliva, E. V., Reissmann, C. B., Gaiad, S., Sturion, J. A., De Olivera, E. B., Wisniewski, C y Miaqui, D. P. Composicao química foliar de macronutrientes em precedencias de erva-mate Ilex paraguariensis St. Hil. Actas del IV Congreso Sudamericano de Yerba Mate. Argentina, 5-8/11/2006, p.285-289. 2006.

Portela, P. M. M. L. (2015). ASPECTOS Nutricionales de vitaminas y Minerales en el siglo XXI , 1ra Edición Asociación Argentina de Tecnólogos Alimentarios. Buenos Aires. Argentina. ISBN 978-987-22165-6-6

Ramirez-mares, M. V., Chandra, S., \& Mejia, E. G. De (2004). In vitro chemopreventive activity of Camellia sinensis, Ilex paraguariensis and Ardisia compressa tea extracts and selected polyphenols, 554, 53-65. https://doi.org/10.1016/j.mrfmmm.2004.03.002.

Rude K. R. (2005). Reference Values for Australia and New Zealand Including Recommended Dietary Intakes. Commonwealth of Australia 2006 .Bone 37 (2005) 211 - 219Nutrient. ISBN Print 1864962372 ISBN Online 1864962437

Scipioni, P. G. (2015). Composición quimica minerales III', in La yerba Mate.Tecnologíade la producción y propiedades, 252-262.

Syedmoradi, L., Ghasemi, A., Zahediasl, S., \& Azizi, F. (2011). Prevalence of hypo-and hypermagnesemia in an Iranian urban population, Annals of human biology, 38(2), 150-155. https://doi.org/10.3109/03014460.2010.500472.

Morck, T. A., Lynch, S. R., \& Cook, J. D. (1983). Inhibition of food iron absorption by coffee. Am J Clin Nutr March, 37(3), 416-420.

Tamilmani, P. \&Pandey, M. C., (2016). Iron binding efficiency of polyphenols: Comparison of effect of ascorbic acid and ethylenediaminetetraacetic acid on catechol and galloyl groups, Food Chemistry. Elsevier Ltd, 197, 1275-1279. https://doi.org/10.1016/j.foodchem.2015.11.045.

Vormann, J. (2003). Magnesium: nutrition and metabolism. Institute Molecular Aspects of Medicine, 24, $27-37$. Https://doi.org/10.1016/S0098-2997(02)00089-4

World Health Organization (2015). The global prevalence of anaemia in 2011. ISBN 9789241564960 (NLM classification: WH 155). http://apps.who.int/iris/bitstream/10665/177094/1/9789241564960_eng.pdf?ua=1\&ua=1

World Health Organization and Food and Agriculture Organization of the United Nations (2004) Vitamin and mineral requirements in human nutrition. Second edition. ISBN: 9241546123.

http://www.who.int/nutrition/publications/micronutrients/9241546123/en/ 
Worthington, V. (2001). Nutritional Quality of Organic Versus Conventional Fruits, Vegetables, and Grains, the Journal of Alternative and Complementary Medicine, 7(2), 161-173. https://doi.org/10.1089/107555301750164244.

Zijp, I. M., Korver, O., \& Tijburg, L. B. M. (2000). Effect of Tea and Other Dietary Factors on Iron Absorption. Critical Reviews in Food Science and Nutrition, 40(5), 371-398. http://dx.doi.org/10.1080/10408690091189194

\section{Copyrights}

Copyright for this article is retained by the author(s), with first publication rights granted to the journal.

This is an open-access article distributed under the terms and conditions of the Creative Commons Attribution license (http://creativecommons.org/licenses/by/4.0/). 